\title{
Assessing Ethno-Ecology of Women in Nepal: Practices and Perspectives
}

\author{
Gem Prasad Gurung ${ }^{1}$ \& Kamal Prasad Koirala ${ }^{2,3}$ \\ ${ }^{1}$ Science Education, Tribhuvan University, Sanothimi Campus, Bhaktapur, Nepal \\ ${ }^{2}$ Science Education, Tribhuvan University, Gorkha Campus, Gorkha, Nepal \\ ${ }^{3}$ Graduate School of Education, T. U, Nepal \\ Correspondence: Kamal Prasad Koirala, Science Education, Tribhuvan University \& Gorkha Campus, Gorkha, \\ Nepal.
}

Received: November 18, 2020

Accepted: December 22, 2020

Online Published: December 24, 2020

doi: $10.5539 /$ mas.v15n1p46

URL: https://doi.org/10.5539/mas.v15n1p46

\begin{abstract}
Women mostly involve in raring and caring natural resources in their daily life. This paper intends to explore the practices and perspectives of Nepali women on ecology conservation in relation to ecological, socio-cultural and religious perspectives. For environmental degradation, women's resource management plays a vital role in ecology conservation. As a qualitative research approach, field observation, focus group discussion, and in-depth interviews with women in the community were the methods of collecting necessary information. Nepali women involve in the collection and management of plant resources in appropriately. Therefore, their perspective and practice can play an important role to minimize the rapid degradation of the environment regarding with management of plant resources. The theoretical literature review consists of movements on environment conservation in the world and in Nepal. No doubt, the message of their contribution will be the lesson to the world for the protection of environment as well as to support and meet the slogan of "local act global think" to save the nature.
\end{abstract}

Keywords: ethno-ecology, socio-culture, religion, livelihood, women group, environment

\section{Introduction}

Ethno-ecology enhances the study of human knowledge, perception, classification, and management of natural environments. This study explores the relationships between biological and physical components in ecosystems. Nepali women often involve in the collection and management of plant resources, but they are ignorant in collecting and managing such resources appropriately. On this issue, cognitive anthropologists also link on the achievement and expression of cultural information. Ethno-ecologists observe the culture as knowledge necessary for ecologically adaptive behavior (Nolan, 2006). Regarding this view, Gerique (2006) opines that ecology can help to understand the dynamic relations between bio-diversity and social and cultural systems.

The term "ethno-ecology" was first coined by Harold Coklin in 1954 conducting a systematic study of plant naming strategies in a small scale of horticulture among the Hanunoo community in the Philippines (Nolan, 2006). Human beings moved ahead to promote their economic and social life standards. Due to the development of science and technology, population growth and their necessities are increasing day by day and to fulfill their unlimited necessities, different industries are being established in different countries. Then the natural resources i.e. fuels, lands, forests, water, etc. are being consumed in an uncontrolled way (Adhikari, 2008) as a result environment degradation has become the main crisis of the world appeared in the forms of water pollution, air pollution, global warming, climate change, etc. (Appannagari, 2017).

Today's world has been glorified by the advancement of modern science and technology, e.g. transportation, telecommunication, economic development, etc. (Muhammad, 2012) which promoted to believe in objective reality rather than spirituality. But the community cannot ignore the religious norms and values concerned with plant conservation in the world. Different religions have different beliefs related to nature and their god/goddesses (WWF, 2000).

The study of the International Union of Conservation of Nature (IUCN, 1997) observed that ninety-three percent of Nepalese women are involved in the collection of natural resources like fodder, fuel, wild food, etc. Adhikari 
(2008) states that women spend their most of the time in a day in the activities like resource collection for their livelihood. As forest and women are deeply interlinked, people believe that women would never intentionally destroy natural resources as their lives highly dependent on them. As a result, it promotes the greenery of earth and environment-friendly performance at their behavior. Such responsibility of women can spread messages and knowledge in society to respect natural resources and preserve them as well.

According to the constitution of Nepal (2072 B. S), Nepal is a multilingual, multicast, and secular country with equal priority to different religions. Therefore, different religious practices are in favour of the management of plants for environmental conservation. They preserve and worship sacred plants like Tulsi, Bar, and Peepal (Gurung, 2018). With this vision, we want to explore the status of women on ecology in Nepal and to identify the ways and measures for promoting ecological management at the local level in Nepal.

\section{The Literature on Ethno-Ecology}

Literature helps to study the research problem (Creswell, 2012). Reviewing of the related study of ethno-ecology, four thematic parts such as; women's movement for ecology conservation in the world, women's knowledge and practices of plant management, religious, ethical and cultural knowledge, and livelihood with sustainability.

\subsection{Women's Movement for Ecology Conservation in the World}

Women's movement on ecology conservation has a great contribution to the world (Adhikari, 2008). Women's movements for ecology conservation appeared at different times. In the mid-1990s, 'Beijing Conference on women, gender agitation, and its study' is prominently seen in social scientists and other individuals for greater understanding of gender to promote environment conservation as well as sustainable development (Ifegbesan, Annegarn, Pendlebury, \& Rampedi, 2016). Rachael Carson made awareness for violation of the environment publishing the book "silent spring" in 1962. Her voice in the book was the earth (forest, water, land) is being polluted by the use of DDT (Gautam, 2003).

Regarding this, Wangari Maathai an African lady also contributed to an effective revolution for plant management in 1977. That event was known as the "Green belt movement". By her contribution, she got a noble prize in 2004. After this movement, Kenyan people got food and shadow. Even today, the people of Kenya give priority to conserving plants (Taylor, 2013).

Vandana Shiva moved around the Indian villages to protect forest resource violations and effects on rural women. The women of India embraced the trees to protect from the woodcutter. That ethnic women's movement is known as "Chipko aandolan" in India. Vandana Shiva was an effective leader among other male leaders. She gained many experiences and wrote many books including staying alive (Gautam, 2003).

In Nepal, women are also working for an environment involving government and non-government organizations. They are leading community forest communities involving as chairman or other members as the provision of forest ministry, Nepal (Forest Act or Nirdesika, 2071 B. S). Non-government organizations of women groups such as WEPCO (Women Environment Preservation Committee) Nepal, Kupondol Lalitpur and Clean up Nepal, Galphutar; and Women in Environment, New Plaza are working in environment preservation in Kathmandu.

\subsection{Women's Knowledge and Practice of Plant Management}

Traditional ecological knowledge is strong among both men and women in the tropics. They are related to religious and cultural knowledge and livelihood sustainability. Religious knowledge is concerned with socio-cultural and ethical aspects. Livelihood knowledge is reflected in, for example, the great variety of plant products collected and used for many different purposes, the practice of numerous agroforestry systems, and the collecting skills which are necessarily based on an in-depth knowledge animal behavior (Tiayon, 2011). In the Rig Vedic period also woman participation is found for environment conservation, which was transformed in different societies as ethno-ecology. Now modern science considers it simply as ecology and environment.

\subsection{Religious, Ethical and Cultural Knowledge}

Religious beliefs, ethical norms values, and cultural life are intricately intertwined with forest resource management (Daniggelis, 2003, p. 94). The women of Indo-Gangetic plain worship the trees like Bel tree (Aegle Marmelos L.) as they believe the sacred tree is associated with Lord Shiva. The sacred tree (Bel) is generally planted near the temple and its garden (Pandey \& Pandey, 2016). In India, the holy plant Tulsi (Ocimum tenuiform $L$.) is grown in front of houses as an auspicious point of view and worshipped by women as a symbol of peace (Pandey \& Pandey, 2016).

Hindu women of India worship the trees of Bar and Peepal as the forms of divine quality. Likewise, Hindu women of Nepal also follow this religious practices and encourage others to worship and conserve them as the 
form of sacred trees. According to Hindu mythology, Brahma was transformed into a Bar tree. The sacred tree is viewed as the male to the Peepal. So people celebrate their (the plants) marriage on the auspicious occasion. Destroying such sacred plants is regarded as a sin in the community (Bhatta, Mukherjee, \& Singh, 1984). Such ethical and cultural knowledge and practices also conserve ecology in the world.

The Kulung Rai of Nepal adopts an indigenous religion that is minimally influenced by Hinduism and Buddhism. According to their belief, deities and spirits live in natural elements like mountains, lakes, forests, and rivers. Likewise, the farmers respect these deities and spirits through puja or rituals and offering food. The Goddess protect Devi than and its territory as the symbol of how women are intimately tied to the forest. Conserved sacred forests in this area promote to preserve rich genetic store house of medicinal plants and protect environment at the local level (Daniggelis, 2003). Women are the main resource users and collectors in this region and this norm may act as additional protection against over exploitation of resources within the groves (Vipat \& Bharucha, 2014).

\subsection{Livelihood and Sustainability}

Gandouz (2018) claims that women and nature are chained like patriarchal manacles, such as nature is damaged by the modern Adam who does not pay much attention to his environment and gives priority to technological development. According to this view, eco-feminism concerns with the importance of women and nature, and accounts for their harmony. Culturally, we see patriarchal and matriarchal societies where male dominant and female dominant families are found respectively. But this study only focuses on fundamental knowledge and practice and perspective on ecology conservation. As mentioned already concerning natural resources, gender shapes the sexual division of labor, knowledge, responsibility, and control. Plant diversity constitutes the greatest part of many indigenous and peasant women's wealth. Women's welfare and social status are also strongly related to their management of plant diversity and their plant-related contribution/function to sustain technical environment and cultural knowledge.

Many women have highly specialized knowledge and practice on the conservation of trees and forests in sustainable management and use for various purposes. They also are aware of the food and medicinal values of forest products, which are important in livelihood as well as the food crisis (UN report, n. d). In central Anatolia (Turkey), some women from villages close to town sell the plants that they have locally collected and produced, creating women's areas in local daily markets where they exchange goods as well as information. There is a significant variation between women's knowledge and their use of edible wild plants (Ertug, 2003). These women in the group prefer to gather the forest resources like greens, medicinal, or fuels. They also agree that not to go out of their village borders. This reflects that women are created and supposed to respect physical and social boundaries for sustainable resource use.

In Tanzania, women collect vegetables from forests, fields fallows, and agroforests (UN report, n. d.). In an interview, African women said that there are lots of products extracted from the forest for their survival. Some are edible products while others are not. People make plenty of income from them to keep the household running (Ifegbesan et al., 2016). They also found that both women and men play important, but different roles in the extraction and conservation of forest resources as women are seen more responsible and involved in the collection, processing, and marketing of different forest products. Therefore, women possess more knowledge of their uses than men.

In Eastern Nepal, Rai and Sherpa women collect forest resources like edible things: medicinal plants, ban tarul (Dioscorea versicolor), wild leafy greens, nutritional fruits, fuels, and grasses in the jungle. They not only collect them but also try to carefully preserve them. The women have a vast knowledge of preserving wild plant resources and ecology (Daniggelis, 2003). The direct impact of environmental degradation in forests and other wild environments is usually on women because they are the primary gatherers, users, and managers of those resources.

\section{Methodology}

This article highlights the contribution of women on ecology conservation through different performances. The study of this article was primarily based on qualitative descriptive study using qualitative methodologies. The qualitative design explores the problem with a detailed understanding of a central phenomenon (Creswell, 2012, p. 16) and as a multi-method, interpretive, and naturalistic approach it explores the socially constructed nature of reality (Denzin \& Lincoln, 2005). The study was based on primary as well as secondary sources of information. Primary sources were drawn from face to face interview with a related person and secondary information were taken from related books, magazines, journals, and websites. 
The data were collected through different methods such as personal interviews, participant observation, and focus group discussion (FGD). To collect information, interview guidelines, observation checklist, and FGD guidelines were developed respectively. The researchers were fully aware of the ethical considerations during the study.

The study was conducted in Gorkha Municipality, Gorkha-6 (Gairi gaun). Informants were selected through purposive sampling regarding where the informants: predefined groups or persons were available. We triangulated the data that were collected applying different techniques to get the trustworthiness of the study (Flick, 2010). In the process of interpretation and meaning-making of text data, we have blended with different theories, philosophies, and literature to draw a real image of social and cultural views. They are also described in the thematic process and reflected the researchers' thoughts.

\section{Result and Discussion}

\subsection{Ethical, Moral and Religious Aspects of Environment Conservation}

Moral, religious aspects and values guide humankind's conduct and harmonize the relationship with nature and the ecology. The ethic of nature conservation is based on a spirit of caring and sharing all faiths and religions. This is the corner stone of the strategy and influencing all thinking and action. Ethical and spiritual faiths are milestones to promote environmental conservation and sustainable tomorrow (WWF, 2000). Brooks and Paul (cited in Mohammad, 2011) observe that there are many overlaps among the laws, ethics and morals including the phenomena. Morals are the basis of law and part of law. While ethics stress a social system in which those morals are applied. The moral includes all religions, conscience, justice and self-consciousness on environment conservation.

In this regard, Getui (1999) said that religion is pervaded in all departments of life so it is not possible to isolate human life. It is related to the maintaining of harmony with natural resources and human beings in the African context. The author adds the African views on nature and its conservation have a huge religious significance. Not only the African context, in all the continent and culture have significant role of ethics, norms and values of environment conservation with regarding to their religion and practice (WWF, 2000). It is therefore cannot be classified so easily looking by as personalist sense of different religions on environment conservation (Gosling, 2001). However, the researchers are exploring for selected field of Gorkha district of Nepal.

An informant (old woman) of Gorkha municipality informed that she always worships to tulsi (Ocimum sanctum) which is planted in her yard. She added more, its Hindus' Sanatan dharma to worship as the form of Laxmi/Vishnu. As we observed in her yard, she also has managed the plants bar and peepal to worship in the form of God. Her family and community have planted bar and peepal on the chautara (platform) of their trails.

They have ethics not to climb and fetch the sacred trees like bar, peepal, bel, etc. They believe in the form of peepal (Ficus religiosa) as Vishnu, bel (Aegle marmelos Corr.) as Shiva, Ashok (Saraca indica Linn.) as Indra, etc. Hindu women said they worship peepal every Saturday pouring water on the root. Under our field observation, we got non-Hindu women (Gurung, Tamang, etc.) also worship to bar (F. bengalensis) and peepal tree. In the interview, they (non-Hindu women) clear that they also believe in those sacred plants as a form of god/goddess. So they are worshipping bar and peepal every Saturday because the day is a good day for bar and peepal. This non-Hindu women knowledge and practice is due to acculturation in their community. No doubt this ethics, moral, and value developed from the Hindu religion is promoting nature conservation.

\subsection{Sustainable Resource Management and Income Generation}

Women are recognized as different managers of natural resources in a sustainable process. The role of rural women in resource management, which directly involved in the production and protection of resources. The major rural energy management, which plays a critical role in attaining the goals of sustainable development (Shailaja, n. d.). The members of Gaira ban samuha reported that they are directly involving in collecting fuel, fodders, and water. If the jungle is destroyed, their livelihood manner will become in difficulties. They viewed that they have to conserve and use the resources in a sustainable process. Regarding the view of women in the field, Sarin (2003) supported that Holta villagers' water resources had dried up, and firewood and fodder had become scarce because of unregulated forest use by surrounding villagers and encroachment on the natural resources.

For the management of resources, the members of Mahila Ban Samuha get together every month and discuss for proper management of their forest resources. Then they establish rule and regulation on how to use and manage forest resources such as time for collection of fuel, local tax system, security guard, and fine for who break the rules. From the forest, they have also developed socio-economic support. In the forest management process, a 
male person is also helping them by giving suggestions, transforming information, watching the jungle from resource poacher. So males are promoting women's program for resource management. In contrast, in different works of literature (Ifegbesan et al., 2016; Shiva, 1989; WWF, 2012) males are dominated to women in different ways. But in the study site, men are supporting women in the work of nature conservation. In the Ban Samuha, we got multicultural women i. e., Brahmin, Magar, Nepali, etc. So it can claim that there is no cast and cultural demarcation among Nepali women for environment conservation.

\subsection{Women's Leadership and Responsibility on Ecology Conservation}

Environmental issues are global challenges and impossible to solve unless women participate fully in efforts to find solutions. On this extent, different women leaders like, Gro Harlem Brudtland, Wangari Mathai, Bandana Siva, etc. have a great contribution to ecology conservation in the world (Gautam, 2003). In the case of Nepal also women are participating directly and indirectly for environment management. Generally, rural areas women are directly connected with forest resources. Therefore, they have more experience in how to keep in balance the resources. So their individual and social efforts on resource management are more effective. In the field, we asked how the women group is managing the community forest. They informed us that it is a committed chairperson, secretary, treasurer, and members. They have committed under Thulo Samudayik Ban Samitee. Different institutions i.e., N/Gos have provided different pieces of training to them for forest management. The district forest office also has provided the right to use and conserve the particular area of the forest. So, they work as the chain in command following their responsibility.

Likewise, they call the meeting every month regularly to discuss their community forest management. If necessary, an immediate meeting is called at any time. In the field observation, we got the forest is well fenced, developed greenery even on the naked land. Sal (Sorea rubusta), chilaune (Schima wallichii), katus (Castanopsis indica), pinus (Pinus roxburghii), etc. are found in the forest and jackal (Canis aureus), rabbit, chituwa (Acinonyx sps.), snake, etc. and different birds are in the case of fauna. It was evidence of their effort on effective forest management as they mentioned.

The committee of Forest User Groups (FUGs) has committed as government provision. The provision in Nepal is that;

1) There should be included 50 percent of women when the community forestry committee is committed.

2) There should be women in vital posts [chairman or secretary].

3) There should be written both man and woman's name when the house owner's name is going to be listed on FUGs or forest conservation group.

4) In the general assembly, there should be presented women/marginalized people. (Nirdesika, 2071, B. S, p. 10).

\section{Recommendations}

Women are the main actors of resource managers in rural areas. Hence it seems the main contribution to solve ecology conservation. Howsoever some policies most me adopted by the government to strengthen their responsibility and participation. Some way and measures are framed below,

It should be fostered women's participation, leadership, and involvement in decision making at all levels.

It should be reorganized women's unpaid care work because they are involving in culinary duty in 24 hours i.e., child/family care to territorial forest care.

Women's knowledge, skill, and practice are oriented on plant resource management. Therefore, support women as "green entrepreneurs".

In many places, women are working in a community forest management committee to manage natural resources. So strengthen women's leadership and entrepreneur's skills.

It should be recognized women's right to forest resources.

It should be rewarded women's groups who are best involved in the conservation of forest heritage/resources.

\section{Conclusion}

The study assesses the efforts to manage natural resources in Prithwi Narayan Municipality in the Gorkha district in Nepal. It has further provided the ecocentric phenomena along with spiritual as well as physical aspects of Nepali women. The study was conducted in a qualitative research methodology. Field data were collected through in-depth interviews, FGD, and observation with their particular guidelines. Analysis of qualitative data 
proceeded based on women's ground knowledge of ritual as well as materialistic knowledge. The findings were Nepali women are conserving plant resources on spiritual aspects as respecting and worshiping sacred plants and the second one is a sustainable resource management and income generation. The third one is women's leadership and responsibility on ecology conservation.

We are feeling very happy to explore Nepali women's contribution to environmental management. The local and global issue was raising for environment pollution by natural resource encroachment. Different national and international conventions were not completely successful to solve the issues of environmental problems. It is hoped that women's potential extent will minimize the global problem of the environment. This study promotes global think local act for ecology conservation. Meanwhile, to fulfill the global aim of ecology conservation through the local level also should be increased by women's entrepreneurs and their empowerment in decision making. Also, the research horizon and speed of this area should be increased by academia and related agencies. Due to the time constraint and logistic support, this study is conducted in a limited area. So, all the environmentalists and concerned authorities should pay their attention to enhance global environment conservation through local women's knowledge and practice of environmental management.

\section{References}

Adhikari, J. (2008). Changing Livelihoods: Essays on Nepal's Development since 1990. Nepal: Martin Chautari.

Appannagari, R. R. (2017). Environmental pollution causes and consequences. A study. North Asian research Journal consortiums, 151-161. Retrieved from https://www.researchgate.net/publication/323944189_environmental_pollution_causes_and_consequences_ A_study

Bhatla, N., Mukharjee, T., \& Singh, G. (1984). Plants: Traditional worshipping. Indian journal of history of science, 19(1), 37-42. $\quad$ Retrieved https://www.insa.nic.in/writeraddata/UpLoadedFiles/IJHS/Vol19_1_4_NBhatla.pdf

Constitution of Nepal. (2072 BS). Sambidhan Sabha Sachivalay. Kathmandu, Nepal. Retrieved from https://www.easynepalityping.com/resource/Constitution_of_Nepal-Nepali-Sanvidhana.pdf

Creswell, J. W. (2012). Educational research; planning, conducting, and evaluating quantitative and qualitative research (4th ed.). New Delhi: PHI Learning Private Limited.

Daniggelis, E. (2003). Women and wild foods: Nutrition and household security among Rai and Sherpa forager-farmers in eastern Nepal. P. L. Haward (Ed.), Women and Plants (pp. 83-97). London and New York: Zed books.

Denzin, N. K., \& Lincoln, Y. S. (Eds.). (2005). Competing definitions of qualitative research method. N. K. Denzin and Y. S. Lincoln, The Sage Hand Book of Qualitative Research (3rd ed.). UK: Sage Publication.

Ertug, F. (2003). Gardening the tradition of plant gathering in Central Anatolia (Turkey). P. L. Haward (Ed.), Women and Plants (pp. 183-196). London and New York: Zed books.

Flick, U. (2010). An introduction to qualitative research (4th ed.). New Delhi, India: Sage Publication India Pvt Ltd.

Gandouz, O. (2018). Mother Nature and Silko's Yellow Women: An ecofeminist Deimension. Science do HSS VII.3 (pp. 1-10).

Gautam, J. (2003). Vishwo paryavarniya andolanma mahila netriharu (Nepali). J. Adhikari \& S. Ghimire (Eds.), Vatavaraniya nyaya: Srot sangalo (pp. 113-120). Nepal: Martin Chautari and Social development and research centre.

Gerique, A. (2006). An introduction to ethnoecology \& ethnobotany theory and methods (pp. 1-21). Retrieved from https://www.researchgate.net/publication/239591352

Getui, M. (1999). Spiritual believes and cultural perceptions of some Kenyan communities. D. A Posey (Ed.), Cultural and Spiritual Values of Biodiversity (pp. 455-457). UK: Intermediate technology publications.

Gosling, D. L. (2001). Religion and Ecology in India and Southeast Asia. London and New York: Routledge.

Gurung, G. P. (2018). Educational perspective of indigenous knowledge and practice of plant management of Gurung community. PhD Thesis: Tribhuwan University, Nepal. 
Ifegbesan, A. P., Annegarn, H. J., Pendlebury, S., \& Rampedi, I. T. (2016). Gender relationships in forest resource utilization and conservation in Nigeria: Implications for environmental sustainability. Gender \& Behavior, 14(1), 6996-7010. Retrieved from https://www.researchgate.net/publication/319321319

IUCN. (1997). Indigenous Peoples and Sustainability: Cases and Action. Netherlands; International Books.

Muhammad, M. (2012). The role of science and technology in development. M. Muhammad, A. B. Garko, M. T. Yakasai \& Y. B. Darala (Eds.), Dynamics in Science and Technology. Nigeria: Ahmadu Bello University Press $\quad$ Limited. Retrieved from https://www.researchgate.net/publication/319456206_The_Role_of_science_and_Technology_in_Develop ment/link/59ac12baa6f

Muhammad, N. (2011). Need to implement the environmental ethics to protect the society: A study on global perspectives for sustainable development. Retrieved from https://www.academicjournals.org/AJBM/artcles-full-text-pdf/32EB8B6124773

Nirdeshika. (2071 BS). Samudaik van bikaskaryakram (Nepali). Nepal Sarkar, Ban tatha Bhusamraxan Mantralaya. Ban bibhag samudayik ban Mahasakha.

Nolan, M. (2006). Ethnoecology $\quad$ (pp. $\quad$ 846-848). Retrieved from https://www.researchgate.net/publication/259486537

Pandey, D., \& Pandey, V. C. (2016). Sacred plants from ancient to modern era: Traditional worshipping towards plants conservation. Tropical plant research, 3(1), 136-141. Retrieved from https://www.tropicalplantresearch.com/archives/2016/vol3issue1/17.pdf

Patton, M. Q. (2002). Qualitative research and evaluation methods (3rd ed.). UK: Sage Publication Ltd.

Sarin, M. (2003). Empowerment and Disempowerment of forest women in Uttarkhand India. G. Kelkar, D. Nathan \& P. Water (Eds.), Gender Relations in Forest Societies in Asia, Patriarchy at Odds. New Delhi: Sage Publications.

Shailaga, R. (n. d.). Women, energy and sustainable development (pp. 1-20). Retrieved from https://www.energia.org/cm2/wp-content/uploads/2015/06/10-women-energy-and-sutainable-development. pdf

Shiva, V. (1988). Staying alive; women ecology and survival in India. New Delhi: Kali for women.

Taylor, B. R. (2013). Kenya's Green Belt Movement: Contribution, conflict, contradictions, and complications in a prominent ENGO. N. Witoszek, L. Tragardh \& B. Taylor (Eds.), Civil Society in the Age of Monitory Democracy (pp. 180-207). Berghahn Books. Retrieved from https://www.researchgate:net/publication/256742718

Tiayon, F. F. (2011). Gender in tropical forestry; realities challenges and prospects. L. Aguilar, D. M. P. Shaw \& A. Q. Aguilar (Eds.), Forest and Gender (pp. 15-18). Switzerland: IUCN. Retrieved from https://portals.iucn.org/library/efiles/documents/2011-070.pdf

UN report. (n. d.). Women in forestry: Challenges and opportunities. Food and Agriculture Organization of United Nations (pp. 1-11). Retrieved from https://www.fao.org/a-i3924e

Vipat, A., \& Bharucha, E. (2014). Sacred groves: The consequences of traditional management. Journal of anthropology, 1-9. https://doi.org/10.1155/2014/595314

WWF. (2000). Religion and Conservation. India: Full Circle.

WWF. (2012). Forest management and gender. Briefing note-WWF-UK (pp. 1-12). Retrieved from https://assets.wwf.org.uk/downloads/women conservation forest 2012.pdf

\section{Copyrights}

Copyright for this article is retained by the author(s), with first publication rights granted to the journal.

This is an open-access article distributed under the terms and conditions of the Creative Commons Attribution license (http://creativecommons.org/licenses/by/4.0/). 